\title{
Fístula liquórica traumática com luxação de globo ocular: relato de caso
}

\author{
Management of globe luxation followed by traumatic liquoric fistula: case report
}

Filipe José Pereira ${ }^{1}$, Ronaldo Brandão de Proença Bettega ${ }^{1}$, Antonio Augusto Velasco e Cruz ${ }^{2}$

\begin{abstract}
This report describes the only case in the literature of globe luxation due to traumatic cerebrospinal fluid fistula to the orbit caused by fire gun with ocular globe maintenance. E.N., female, white, 7 months, admitted with left orbitocranial injury by fire gun. Ocular globe luxation was detected with complete ocular motility restriction and absence of pupillary reflex in the left orbit. Computed tomography showed fracture of the medial orbital wall; bone fragments near the apex of the orbit and a stretched optic nerve. Surgical exploration was performed, showing liquor fistula through the ethmoid-sphenoid wall that was blocked with sponge (Gelfoam ${ }^{\circledR}$ ) plus organic glue in the left orbit posterior wall, with immediate resolution of the proptosis and ocular integrity maintenance. Although controversial, maintenance of the ocular globe instead of enucleation was performed due to the integrity of the globe in this case. Despite the blindness, we considered the result to the proposed treatment excellent, once the maintenance of the ocular globe provides a good appearance and will contribute to an adequate facial bone development.
\end{abstract}

Keyword: Fistula; Cerebrospinal fluid; Eye injuries; Wounds, gunshot/complications; Orbit/pathology; Optic nerve injuries/surgery; Tomography, x-ray; Human; Female; Infant; Case reports

\begin{abstract}
RESUMO
O presente estudo apresenta o único caso de luxação de globo ocular devido fístula liquórica traumática em vítima de trauma órbito-cerebral por projétil de arma de fogo com a preservação do globo ocular. E.N., feminino, branca, 7 meses, admitida com ferimento por projétil de arma de fogo em região órbito-craniana esquerda. Apresentava luxação de globo ocular esquerdo com restrição completa da motilidade ocular e reflexo fotomotor ausente à esquerda. À tomografia: fraturas da parede medial da órbita; fragmentos ósseos próximos ao ápice da órbita. Realizou-se exploração cirúrgica, evidenciando-se fístula liquórica através de fratura etmoidoesfenoidal a qual foi tamponada com esponja (Gelfoam ${ }^{\circledR}$ ) e cola orgânica na parte posterior da parede medial da órbita esquerda, com regressão imediata da luxação do globo ocular, sendo o mesmo mantido íntegro. Embora controversa na literatura, optou-se pela preservação do globo ocular à enucleação, visto que o mesmo estava integro. Apesar da cegueira, consideramos um excelente resultado ao tratamento proposto, tendo em vista que a preservação do globo ocular provém uma boa aparência, favorecendo também o desenvolvimento ósseo da face.
\end{abstract}

Descritores: Fístula; Líquido cefalorraquidiano; Traumatismos oculares; Ferimentos por arma de fogo/complicações; Orbita/patologia; Traumatismos do nervo óptico/ cirurgia; Tomografia por raios x; Humanos; Feminino; Lactente; Relatos de casos

\section{INTRODUCTION}

0 cular trauma is one of the main causes of ocular morbidity and blindness in children. It has great importance in public health, involving medical care, long-term of morbidity, school absence, long-term disabilities and economic impact. However, approximately $90 \%$ of ocular injuries could be prevented with relative simple methods because the highest incidence occurs in the domestic environment, followed by car accidents ${ }^{(1)}$.

According to some studies, cutting objects (35.1\%) and noncutting objects (22.6\%) are the principal causes of trauma, followed by fire weapons (6.9\%); sand, dust and wood particles (6.6\%); and chemical products (5.1\%). Usually they are associated with craniumencephalic lesions and facial fractures. Males are more frequently reported (64.9\%) to have eye injuries than females. Results varied across studies regarding the age-specific frequency of eye injuries, with some reporting a higher incidence in older children and others in younger children ${ }^{(2-5)}$.

Trabalho realizado no Departamento de Plástica Ocular do Hospital Governador Celso Ramos Florianópolis (SC) e Centro de Estudos de Oftalmologia Dr. Aramis Ritzmann Mendes.

Médico, Departamento de Plástica Ocular, Hospital Governador Celso Ramos - HGCR - Florianópolis (SC), Brasil.

${ }_{2}$ Médico, Departamento de Oftalmologia, Otorrinolaringologia e Cirurgia de Cabeça e Pescoço,

Faculdade de Medicina de Ribeirão Preto, Universidade de São Paulo - USP - Ribeirão Preto (SP),

Brasil.

Endereço para correspondência: Filipe José Pereira. CCPO - Clínica Catarinense de Plástica Ocular. Rua Dom Jaime Câmara, 179 - SI. 704/705 - Florianópolis (SC) - CEP 88015-120

E-mail: filipeccpo@uol.com.br

Fontes de auxilio à pesquisa: livros oftalmológicos/publicações internet

Recebido para publicação em 18.08.2008

Última versão recebida em 25.01.2010

Aprovação em 08.02.2010
Orbit fire gun lesions have several clinical aspects such as globe perforation; orbital celullitis; arteriovenous or cerebrospinal fluid fistula; fractures; ocular globe luxation; optic nerve lesion and others ${ }^{(2-5)}$.

There is only one case report in literature of globe luxation after optic nerve avulsion by gun fire, in a 38 years old patient, without light perception in the affected eye, which was submitted to enucleation ${ }^{(6)}$.

This study reports the only case in the literature of globe luxation due to traumatic cerebrospinal fluid fistula to the orbit by fire gun in a 7 month child.

\section{CASE REPORT}

E.N., female, $7 \mathrm{~m}$, admitted in the emergency of Hospital Infantil Joana de Gusmão (Florianópolis) with left orbito-cranial injury by gun fire.

In 01.19.2003, the child was admitted in the intensive unit care with antibiotic therapy (ceftriaxone), followed by surgical exploration by neurosurgeon - projectile enter orifice and duramater cleaning, with removal of non-viable debris. On the 1st postoperative day (Figure 1) our first ophthalmological evaluation detected a luxation of the globe (previous to the neurosurgery) with complete restriction of ocular motility, superior eyelid hematoma, severe chemosis, and a fixed and dilated left pupil. Ophthalmoscopy was normal.

A computed tomography (CT) was performed showing us hemorrhage and contusions at the base of the left frontal and temporal region and a projectile lodged in the left mastoid. Fractures of the lamina papiracea and posterior-medial orbit wall were found. Proptosis was due to the fluid collection in the superior-medial orbit portion. Bone fragments that points to optic nerve damage were present near the optic canal. 
Surgical exploration was performed using an anterior approach, showing liquor fistula through the ethmoid-sphenoid wall that was blocked with sponge $\left(\right.$ Gelfoam $\left.^{\circledR}\right)$ plus organic glue in the left orbital posterior wall, with immediate resolution of the proptosis. After the surgery, she presented with left eyelid edema and normotensive orbit. Direct pupillary reflex on the left eye remained absent. (Figure 2) The patient had improved clinically.

Last examination was performed on 08.10.2006 with good scar, and at that time it was noted that the patient had no motility restriction but a mild ptosis was detected (superior MRD $=2,5 \mathrm{~mm}$ ). This ptosis will be treated at some time in the near future.

\section{DISCUSSION}

In the present study, a 7 month's child was victim of orbitocranial injury by fire gun projectile with optic nerve lesion, orbital wall fracture and intracranial foreign body. It is a difficult case because multiple complications are inherent and threatful, so it has to be treated as soon as possible with broad-spectrum parental antibiotics, tetanus prophylaxis and anticonvulsant medication (30\% incidence of epilepsy). Survival rate is $90 \%$ when early surgical intervention to remove the foreign body is done, whereas nonintervention has a 30\% survival rate. Ophthalmologic and neurosurgical evaluation with a careful follow-up are essential for any patient with penetrating orbitocranial injury ${ }^{(7-9)}$.

The nature of the foreign body influences the risk of infection, with wood and vegetable material providing the most infective sources, which does not fix in the presented case, wich is metallic material ${ }^{(8)}$.

The patient developed liquoric fistula, which was manifested by fluid leakage through the orbital structure and lids edema ${ }^{(8)}$.

In this case, the propellant force were created by the fire gun projectile, and by entering at the posterior orbital region, protrude
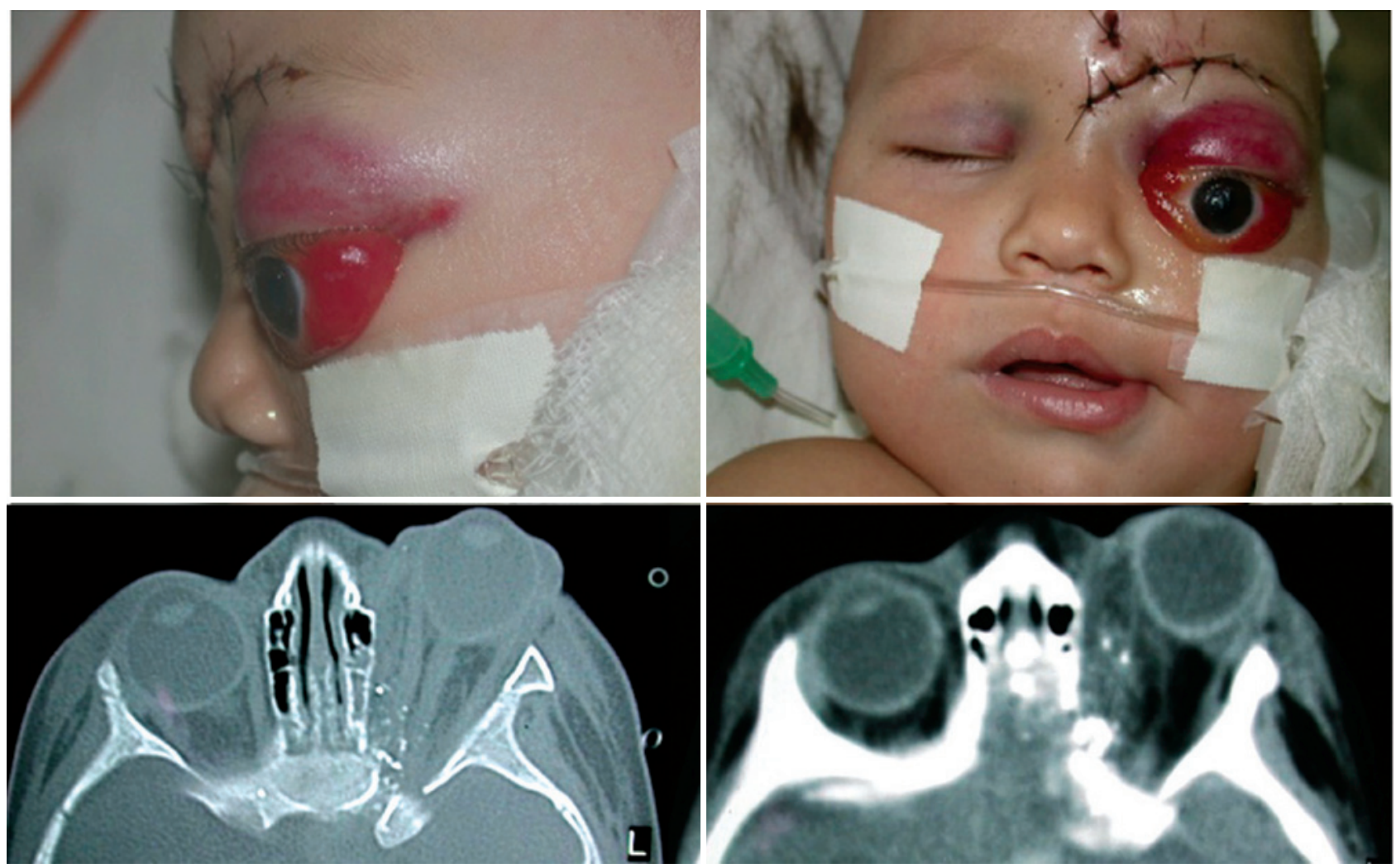

Figure 1. $1^{\text {st }}$ day after neurosurgery showing luxation of the globe, CT scan showing projectile, bone fragments and proptosis at left.
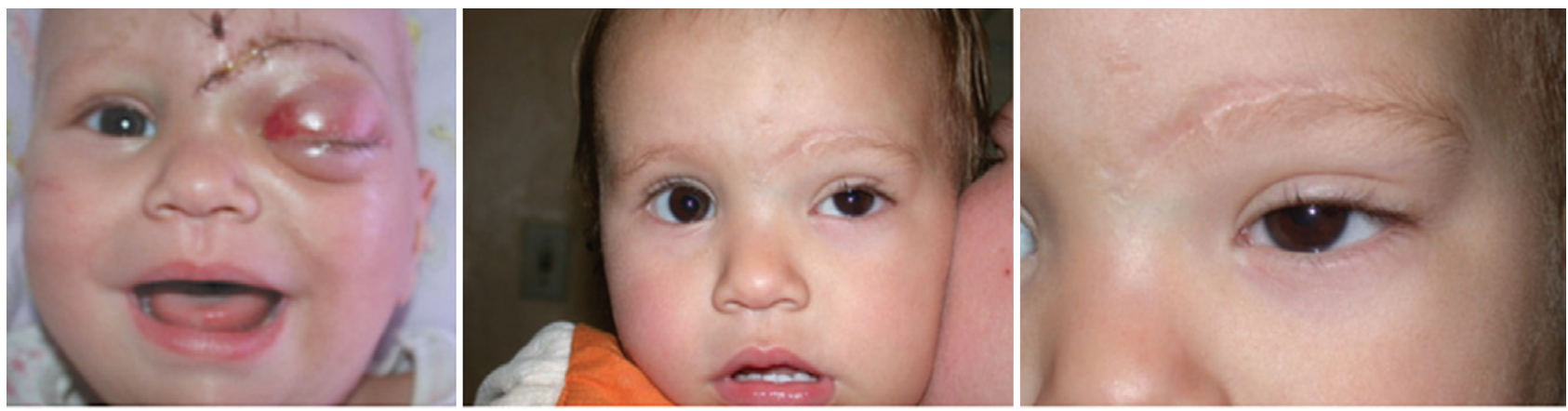

Figure 2. ${ }^{\text {st }}$ day after liquoric fistula blockage and patient at 4 years-old. 
the ocular globe without breaking the optic nerve fibers at CT. The optic nerve lesion in its insertion at the ocular globe is facilitated by nerve fibers vulnerability at the optic disc and scleral wall fragility, by the crivous lamina. There are some papers describing that CT can be normal even with optic nerve avulsion ${ }^{(8-9)}$.

The orbital exploration should be done searching foreign bodies, signs of globe disruption and hemorrhages. Any type of traumatic enucleation can develop an orbital infection, liquor leakage, subaracnoidal hemorrhage, meningitis and hipotalamic break down, with endocrine disruption ${ }^{(6-10)}$.

Some authors recommend a quick replacement of the globe back to the orbit, since there is not an ocular globe posterior disruption (optic nerve avulsion only in the pre-laminar and crivous lamina portions). In these cases, a decrease on the edema and an improvement in the blood flow would avoid the ischemia and the phthisis bulbi development ${ }^{(7)}$.

Other authors suggest primary enucleation to the treatment of ocular globe luxation with optic nerve avulsion. We disagree, and according with several authors, we believe in the benefits of ocular globe maintenance, since in this case the globe was intact. One example is the case of an 18 months child, whose luxated globe, after a traumatic disruption of the optic nerve, were replaced to allow a symmetric facial development and a important psychological gain to the patient ${ }^{(10)}$.

A primary enucleation in ocular trauma is questionable, being indicated when a functional and anatomical restoration of the globe is impossible or to avoid the sympathethic ophthalmia occurrence. Therefore, it is mostly indicated only in the lost of ocular globe integrity ${ }^{(6-7,9-10)}$.

In this study, a liquor fistula to the left posterior-medial wall of the orbit were blocked with sponge $\left(\right.$ Gelfoam $\left.^{\circledR}\right)$ plus organic glue, with immediate resolution of ocular globe luxation and maintenance of globe integrity.

The treatment was rapidly performed, after use of antibiotics and anticonvulsants by the pediatrician and neurosurgeon approach, showing the necessity of a multidisciplinary team to the correct treatment of orbitocranial trauma, decreasing the inherits risks ${ }^{(7,9)}$

Instead the blindness, we considered an excellent result to the treatment proposed, so that the maintenance of ocular globe provides a good appearance, collaborating to the facial bone development, besides, release psychological consumption in enucleated patients and all its potential disturbances.

\section{REFERENCES}

1. Negrel AD, Thylefors B. The global impact of eye injuries. Ophthalmic Epidemiol. 1998;5(3): 143-69. Comment in: Ophthalmic Epidemiol. 1998;5(3):115-6.

2. Strahlman E, Elman M, Daub E, Baker S. Cause of pediatric eye injuries. A population-based study. Arch Ophthalmol. 1990;108(4):603-6.

3. MacEwen CJ. Ocular injuries. J R Coll Surg Edinb. 1999;44(5):317-23.

4. May DR, Kuhn FP, Morris RW, Witherspoon CD, Danis RP, Matthews GP, et al. The epidemiology of serious eye injuries from the United States Eye Injury Registry. Graefes Arch Clin Exp Ophthalmol. 2000;238(2):153-7.

5. Moreira CA Jr, Debert-Ribeiro M, Belfort R Jr. Epidemiological study of eye injuries in Brazilian children. Arch Ophthalmol. 1988;106(6):781-4.

6. Tarcia RA. [Traumatic optic nerve avulsion by high caliber bullet: case report]. Arq Bras Oftalmol. 2006;69(3):417-20. Portuguese.

7. Vaicys $C$, Hunt $C D$, Heary RF. Successful recovery after an orbitocranial injury. J Trauma. 2000; 49(4):788.

8. Hoffman JR, Neuhaus RW, Baylis HI. Penetrating orbital trauma. Am J Emerg Med. 1983; 1(1):22-7.

9. Bajaj MS, Pushker N, Nainiwal SK, Balasubramanya R. Traumatic luxation of the globe with optic nerve avulsion. Clin Experiment Ophthalmol. 2003;31(4):362-3.

10. Vogt $P$, Motsch S, Mühlendyck H, Hommerich CP. [Management of unilateral traumatic bulb luxation with disruption of the optic nerve]. HNO. 2003:51(2):146-50. German 